\title{
Comparative Study of Different Milk Samples Preservation Procedures for Bacteriologic Examination
}

\author{
Nathalie Gnanou Besse • Alexandra Cauquil • \\ Marie-Léone Vignaud • Léna Barre • \\ Véronique Deperrois · Elodie Voitoux • \\ Marie-Bernadette Obabaka $\cdot$ Bertrand Lombard
}

Published online: 6 September 2008

(C) Springer Science + Business Media, LLC 2008

Erratum to: Food Anal. Methods

DOI 10.1007/s12161-007-9009-9

Please note two corrections to the above article.

The L. monocytogenes strain mentioned in the first sentence of the first paragraph of the Materials and Methods section should have been noted as 10 and was isolated from cheese, not cold-smoked salmon as published.

The online version of the original article can be found at http://dx.doi. org/10.1007/s12161-007-9009-9.

N. Gnanou Besse $(\triangle) \cdot$ A. Cauquil $\cdot$ M.-L. Vignaud $\cdot$ L. Barre $\cdot$

V. Deperrois $\cdot$ E. Voitoux $\cdot$ M.-B. Obabaka $\cdot$ B. Lombard Agence française de sécurité sanitaire des aliments, Afssa,

Laboratoire d'Etudes et de Recherches sur la Qualité des

Aliments, et sur les Procédés agro-alimentaires (Afssa),

23 avenue du Général de Gaulle,

94706 Maisons Alfort cedex, France

e-mail: n.besse@afssa.fr 